\title{
CFD modelling of hydrogen starvation conditions in a planar Solid Oxide Fuel Cell
}

\author{
Paulina Pianko-Oprych*, Tomasz Zinko, Zdzisław Jaworski \\ West Pomeranian University of Technology, Institute of Chemical Engineering and Environmental Protection Processes, \\ Faculty of Chemical Technology and Engineering, Szczecin, al. Piastów 42, 71-065 Szczecin, Poland \\ "Corresponding author: e-mail: paulina.pianko@zut.edu.pl
}

\begin{abstract}
The aim of this study was to highlight the interest of using CFD technique as a diagnostic tool of a malfunctioning Solid Oxide Fuel Cells. Hydrogen starvation of a SOFC due to nitrogen dilution is one of the cell dysfunctions and can lead to its degradation. Identification of the starvation point allows to improve cell performance and establish the best conditions for degradation tests. To illustrate a potential of the CFD tool, several simulations of a single planar SOFC and its behaviour under hydrogen starvation were performed and analysed. The results showed that at lower cell voltage values of 0.3 and $0.5 \mathrm{~V}$ significant gradients in the electric current were noticed due to a local reduction in hydrogen concentration. The CFD analysis allowed defining desirable mass flow rate of hydrogen to SOFCs to avoid fuel starvation. The model constitutes a helpful tool for optimizing cell design and operational conditions.
\end{abstract}

Keywords: planar Solid Oxide Fuel Cell, fuel starvation, current density, CFD modelling.

\section{INTRODUCTION}

Among various types of fuel cell, Solid Oxide Fuel Cell (SOFC) was chosen for this study as a result of its low emission as well as possible combined electric and thermal efficiencies of more than $90 \%{ }^{1}$. Due to its high working temperature $\left(600-1000^{\circ} \mathrm{C}\right)$ hydrocarbon fuel with internal reforming can be used and the remaining thermal energy produced with exhausted gases can be utilized for heating water or space in a cogeneration system. Therefore, SOFC has been thought to be a promising, innovation power and thermal energy generation solution. However, to deliver adequate cogeneration system for commercial stationary applications, the performance characteristics of the SOFC have to be examined. The use of simulation seems to be the perfect tool in this case, because it allows to overcome the barrier related to technical challenges in fuel cell technology as well as to reduce the costs of experimental investigations. Detailed mathematical models of fuel cells have been developed by various researchers ${ }^{1,2}$ and fundamental knowledge of fuel cells operational behaviour, transport phenomena as well as thermal and electrical efficiencies have been already gained. Nevertheless, it seems that some effects of physical processes occurring in the fuel cell need still further attention. One of these issues is related to correctly predicting local fuel starvation which can be difficult to assess during experimental investigation due to technical barriers, while it is important to understand the SOFC operating conditions.

Perfectly uniform current density is almost impossible to attain in practice in a Solid Oxide Fuel Cell. Minimizing current density gradients reduces current density hotspots, hence it can avoid local high fuel utilization and fuel starvation in the extreme case ${ }^{3}$. Thus, minimizing the gradients of this key fuel cell variable in all three dimensions is always of interest. However, during experiments the distributions of current density, species or temperature in a cell are not easy to determine. It is usually unknown if the reactants are poorly depleted by the reaction products or fully consumed by complete combustion. If this is the case, then the remaining portion of the cell cannot generate enough power, thus the power density distribution could not be uniform over the whole cell surface. During measurements even the gas velocity in the cell may differ from that supplied at the gas chamber inlet ${ }^{4}$. Therefore, one of the numerous problems of poor performance of SOFC results from the mass transport limitation across the cell.

Dysfunction of a SOFC can be also due to several other causes, such as chemical or electrochemical degradation due to formation of chemical compounds at $\mathrm{Ni}$ surface, which disable active sites at the surface by blocking heterogeneous reactions and obstructing charge-transfer reactions of three-phase boundary, as well as due to formation of solid carbon inside the electrode or again fuel starvation ${ }^{5}$. Fuel starvation can be the main problem if the cell consumes electrochemically active fuel constituents more rapidly than the fuel supply system can provide them. A low hydrogen mole fraction causes the current to decline sharply, which can cause the power produced by the fuel cell to drop. If the anode becomes fuel starved, little or no power can be produced by the cell and it can be permanently damaged as the material in the anode becomes oxidized ${ }^{6}$. Fuel starvation can also occur during rapid load increase if no action is taken to prevent it and therefore it is an important fuel cell operating constraint.

In order to effectively control fuel cell several methods have been identified in the literature ${ }^{7-9}$. The simulation results ${ }^{7,8}$ confirmed that the models are able to capture the overall dynamics behaviour of the SOFC. Several failure modes and effect analysis of the pumps for oxidant and fuel, fuel and air starvation conditions were simulated by applying electrical loads for $1-2 \mathrm{~h}$ without supplying any hydrogen and air or supplying 3\% vol. humidified hydrogen'. It was shown that the anode fuel starvation by the fuel pump failure resulted in delamination of the interface between the anode/electrolyte and electrolyte/ cathode due to the extensive volume change of the $\mathrm{NiO}$ anode. To provide evidence of the degradation of SOFC various electrochemical and physical-chemical analyses were performed including I-V curves, electrochemical 
impedance spectroscopy as well as electrode polarization. Those measurements are costly, time consuming and require specialized equipment. Additional difficulty lies in the need to obtain polarization curves before and after the starvation experiment under the same test conditions. Chen et al. ${ }^{\mathbf{1 0}}$ tried to understand the rapid degradation mechanism of a thin Nickel-Cerium Gadolinium Oxide (Ni-CGO) anode in a Strontium-doped Lanthanum Manganite-Cerium Gadolinium Oxide (LSM-CGO) cathode supported SOFC operated with low concentration of hydrogen at high current density. Experiments were carried out at $800^{\circ} \mathrm{C}$ by stepwise increasing of current density in the SOFC circuit. It was found that degradation of the anode can be due to re-oxidation of $\mathrm{Ni}$ by $\mathrm{O}^{2-}$ and/or by the produced water steam at a higher current density. The performance of the degraded cell was unable to be directly recovered by hydrogen reduction unless the anode was firstly burnt in oxygen before reduced in hydrogen ${ }^{\mathbf{1 0}}$. A redox cycle can occur for several reasons such as: thermal cycle of a SOFC system during shut down and start-up operations, cutting-off gas supply in the case of an emergency situation, oxidation from steam in the SOFC system with steam reforming, leakage through a sealing, too high hydrogen conversion rate, high fuel dilution or finally local fuel starvation caused by a load. It has to be underlined that fuel starvation process is one of the most dangerous factors of anode degradation due to microstructure changes ${ }^{\mathbf{1 1}}$.

However, there is no published consensus in this field. Some authors reported massive degradation due to fuel starvation $^{\mathbf{1 2}}$, while other authors reported no significant degradation ${ }^{\mathbf{1 3}}$. Hatae et al. ${ }^{\mathbf{1 3}}$ noticed that when their $\mathrm{Ni}$ particles were oxidized at $25 \mathrm{~mA} / \mathrm{cm}^{2}$ the morphological change in the Ni particles and anode were very small. On the other hand, when $\mathrm{Ni}$ particles were oxidized at 250 $\mathrm{mA} / \mathrm{cm}^{2}$, rapid electrochemical oxidation took place and the Ni microstructure changes led to micro-cracks in the anode layer and delamination at the interface between the electrolyte and anode layers ${ }^{\mathbf{1 3}}$. Local oxidation of cells can take place at very high fuel utilization of $90 \%$. Fuel utilization is an important parameter for evaluating fuel cell performance and it is not only determined by the electrochemical properties of the anode, but it is also dependent on the fuel distribution inside cells ${ }^{\mathbf{1 4}}$. Therefore, a homogeneous fuel distribution is required and it can be obtained only in the case, when a proper design of the flow field and gas manifolds are provided.

Many studies try to optimize SOFC design to operate at high fuel utilization of above $70 \%{ }^{15-19}$. For microtubular SOFCs operated at fuel utilization above 50\%, Majewski and Dhir ${ }^{16}$ as well as Torrell et al. ${ }^{17}$ reported a risk of expansion of $\mathrm{Ni}$ agglomerates. The changing Ni volume can detach electrolyte from anode and, as a consequence, reduce the cell electrochemical activity. At high fuel utilization, electrochemical oxidation may occur due to fuel starvation ${ }^{\mathbf{1 8}}$. In turn, Koshiyama et al. ${ }^{\mathbf{1 9}}$ optimized the separator design to improve the output power and durability of the electrolyte supported planar SOFC at high fuel utilization. It was shown that an increase in the anode rib width gives Open Circuit Voltage (OCV) drop and large overpotential under the rib due to fuel starvation. However, hydrogen/oxygen partial pressure distributions derived by Finite Element modelling, ad- justed to give measured segment currents, support the experimental results. Thus, the authors ${ }^{\mathbf{1 9}}$ demonstrated feasibility of the measurement based modelling as a useful tool in improvement of the separator design for a stack. The initial current distribution as well as fuel and oxygen distributions inside the anode can be significantly altered also by the contaminant coverage of $10 \mathrm{ppm}$ of phosphine in the fuel channel. Results ${ }^{20}$ show that after initial transients, there was a rapid degradation. Current redistribution caused by contaminant induced deactivation of some regions of the cell resulted in hydrogen starvation in the active regions, which in turn led to oscillations in the voltage and current. Flexibility of simulations and predictions of the I-V behaviour of a cell was presented in the paper ${ }^{20}$. A 3D CFD model was also applied to an anode-supported planar SOFC to investigate transport phenomena inside a fuel cell fed with hydrogen and to evaluate its overall performance ${ }^{\mathbf{2 1}}$. It was found that temperature gradients existed along the length of the cell and therefore the maximum value of temperature for the cross-flow was at the outlet of the cell. Thus, the current density distribution was uneven and the maximum current density was found at the interfaces between the channels, ribs and the electrodes. The maximum current density resulted in a large overpotential and heat source in the electrodes, which was harmful to the overall performance of the fuel cell. Zhang et al. $^{21}$ proposed a new type of flow structure to make the current flow more evenly distributed and promote most of the triple phase boundary areas to take part in electrochemical reactions.

Encouraged by the good results achieved with the SOFC by Zhang et al. ${ }^{21}$, we decided to continue the numerical investigations $^{24}$ of the single planar SOFC behaviour under high fuel utilization and possibly high current densities. The numerical CFD results ${ }^{\mathbf{2 4}}$ were obtained at hydrogen mass flow rate equal to the experimental value and revealed non-uniform current density over the cell length.

Motivation for the present work stems from the need to correctly predicting local fuel starvation in order to avoid destructive nickel oxidation of the anode electrode. It is important to understand the SOFC operating conditions and its influence into cell behaviour. Thus, it was decided to illustrate a potential of the CFD tool in investigations of a single planar anode-supported Solid Oxide Fuel Cell behaviour. Calculation of gas velocities, species and current density distributions by modelling was presented. In addition, a hypothesis explaining the deviations of numerical CFD predictions from experimental results was defined and tested.

\section{NUMERICAL APPROACH}

The geometry used in this paper based on a tested design of anode-supported planar SOFC developed by Bossel $^{22}$. The complete SOFC domain consists of a Strontium-Dopped Lanthanum Manganite (LSM) cathode, a thin Yttria-Stabilized Zirconia (YSZ) electrolyte and an Nickel/Yttria Stabilized Zirconia (Ni/YSZ) anode. Figure 1 displays the sketch of the SOFC interconnect with ribs defined in the graphical pre-processor ANSYS Workbench 15.0. 


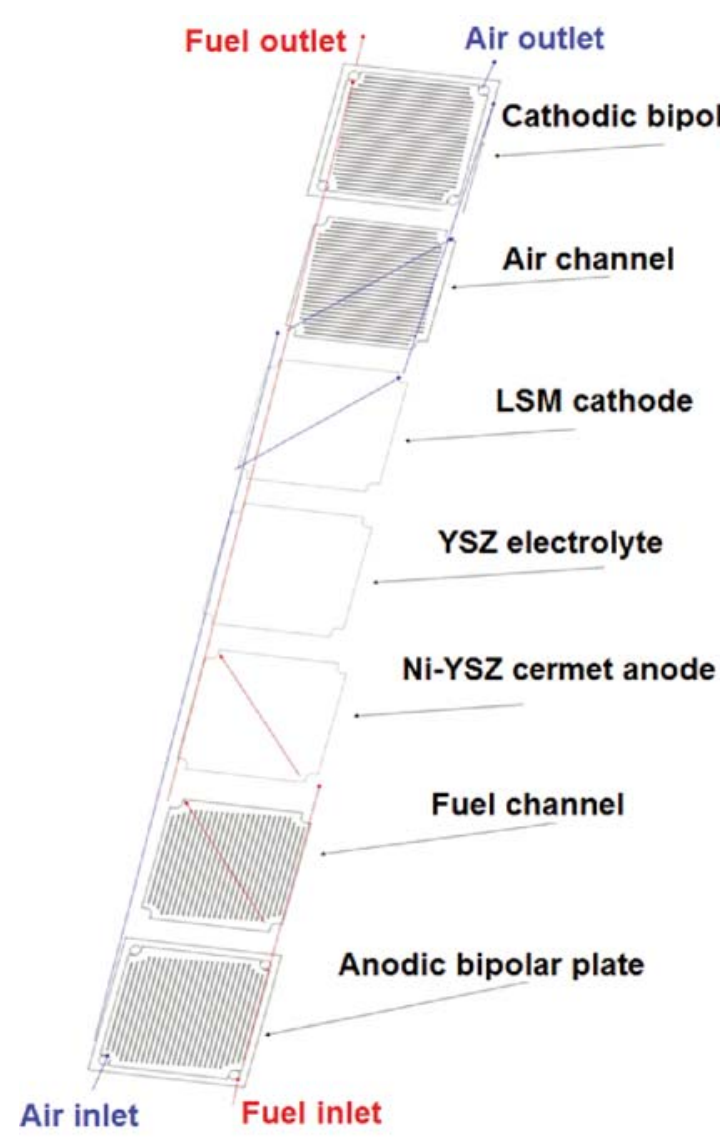

Figure 1. The sketch of the SOFC geometry

The computational domain includes 3D unstructured mesh (Fig. 2) of 890 thousand computational cells built in the ANSYS Meshing 15.0. The mesh is finer in the anode and cathode layers, while coarser for the air and fuel channels and for the interconnectors. Based on the orthogonal quality and element quality parameters, it was found that the quality of the mesh was good because the value of the chosen parameter was equal to 0.59 and was inside the available range.

A 3D computational model was developed in the commercial CFD code ANSYS Fluent 15.0 with an additional ANSYS Fuel Cell Tools module. During the simulations the mass and heat transfer, fluid flow and species transport as well as the electric field in the flow channels and in the porous electrodes were considered. The transport equations were coupled with electroche-

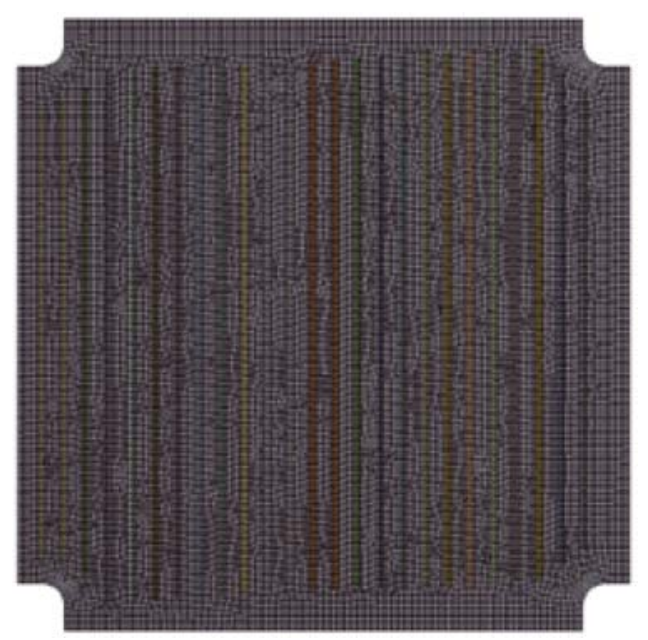

Figure 2. The mesh for the anode-supported planar SOFC mical processes through source terms used to describe the relevant processes in fuel cells. Thus, the electrolyte was treated as "interface" (zero thickness layer) in the applied approach and had two functions. First of all, its main task was to transport oxygen ions from the cathode to the anode side and second to block electron as well as gas flow between the anode and cathode. The electron transport was considered in order to collect current from the fuel cell. Species transport through the porous electrodes occurs in the gas phase and was integrated with the electrochemical reactions. The electrodes were considered as porous media and species transfer was dominated by the gas diffusion. All gas streams were regarded as incompressible laminar flows due to low velocity along the thin channels. Fuel and air were modelled using the ideal gas assumption due to the high operational temperature and low pressure. Based on the same assumption of ideal gas mixing law, the other basic properties such as heat capacity, viscosity and thermal conductivity of the gaseous species were calculated in the CFD code. The governing equations for mass balance (Eqs. 1-10), momentum balance (Eqs. 12-13) as well as energy balance (Eqs. 14-18) and charge balance (Eqs. 19-24) solved in the model are presented below.

Anode

$\nabla\left(\rho_{\text {fuel }} \bar{v}_{H_{2}}-\rho_{\text {fuel }} x_{H_{2}} \sum_{k=1}^{N} D_{H_{2}, k}^{e f f} \nabla x_{i}\right)=R_{H_{2}}$

$\nabla\left(\rho_{\text {fuel }} \bar{v}_{H_{2} \mathrm{O}}-\rho_{\text {fuel }} x_{H_{2} \mathrm{O}} \sum_{k=1}^{N} D_{H_{2} O, k}^{e f f} \nabla x_{i}\right)=R_{H_{2} O}$

$\nabla\left(\rho_{\text {fuel }} \bar{v}\right)=\mathrm{R}_{\mathrm{H}_{2}}+\mathrm{R}_{\mathrm{H}_{2} \mathrm{O}}$

Cathode

$\nabla\left(\rho_{\text {air }} \bar{\nu}_{O_{2}}-\rho_{\text {air }} x_{O_{2}} \sum_{k=1}^{N} D_{O_{2}, k}^{e f f} \nabla x_{i}\right)=R_{O_{2}}$

$\nabla\left(\rho_{\text {air }} \bar{v}\right)=R_{\mathrm{O}_{2}}$

Fuel channel

$\nabla\left(\rho_{\text {fuel }} \bar{v}_{H_{2}}-\rho_{\text {fuel }} x_{H_{2}} \sum_{k=1}^{N} D_{H_{2}, k}^{e f f} \nabla x_{i}\right)=0$

$\nabla\left(\rho_{f u e l} \bar{\nu}_{H_{2} O}-\rho_{f u e l} x_{H_{2} O} \sum_{k=1}^{N} D_{H_{2} O, k}^{e f f} \nabla x_{i}\right)=0$

$\nabla\left(\rho_{\text {fuel }} \bar{v}\right)=0$

Air channel

$\nabla\left(\rho_{\text {air }} \bar{v}_{O_{2}}-\rho_{\text {air }} x_{O_{2}} \sum_{k=1}^{N} D_{O_{2}, k}^{e f f} \nabla x_{i}\right)=0$

$\nabla\left(\rho_{\text {air }} \bar{v}\right)=0$

The effective mass diffusivity coefficient, $D_{i, k}^{\text {eff }}$, was approximated by the function of the electrode porosity, $\varepsilon$, tortuosity factor, $\tau$, and binary diffusion coefficient, $\mathrm{D}_{\mathrm{i}, \mathrm{k}}$ (Eq. 11):

$D_{i, k}^{e f f}=\frac{\varepsilon}{\tau} D_{i, k}$ 
Anode/Cathode

$\nabla\left(\varepsilon \rho_{\text {gas }} \overline{\mathrm{vv}}\right)=-\varepsilon \nabla \mathrm{p}+\nabla\left[\varepsilon \mu_{\text {gas }}(\nabla \bar{v}+(\nabla \mathrm{v}))^{\mathrm{T}}\right]-\frac{2}{3} \varepsilon \nabla \mathrm{v} \mathrm{I}$

Air/fuel channels

$\nabla\left(\rho_{\text {gas }} \overline{\mathrm{vv}}\right)=-\nabla \mathrm{p}+\nabla\left[\mu_{\text {gas }}(\nabla v+(\nabla v))^{\mathrm{T}}\right]$

Thermal energy was transferred by conduction and convection, however the radiative heat transfer was neglected due to its low impact ${ }^{23}$.

Anode

$\nabla(-k \nabla T)=\frac{R_{H_{2, \text { anode }}} T\left(S_{H_{2} \mathrm{O}}-\frac{1}{2} S_{\mathrm{O}_{2}}-S_{\mathrm{H}_{2}}\right)}{M_{\mathrm{H}_{2}}}+$

$+n_{H_{2, \text { anode }}}\left|Q_{H_{2, \text { andedelece }}}\right|+\frac{i_{\text {ion }}^{2}}{\sigma_{\text {anode, ion }}}+\frac{i_{\text {elec }}^{2}}{\sigma_{\text {anode,elec }}}$

\section{Electrolyte}

$\nabla(-\mathrm{k} \nabla \mathrm{T})=\frac{\mathrm{i}_{\text {ion }}^{2}}{\sigma_{\text {elec, ion }}}$

Cathode

$\nabla(-k \nabla T)=n_{O_{2, \text { cathode }}}\left|Q_{O_{2, \text { cathode-elec }}}\right|+\frac{i_{\text {ion }}^{2}}{\sigma_{\text {cathode,ion }}}+\frac{i_{\text {elec }}^{2}}{\sigma_{\text {cathode,elec }}}$

Inter-connectors

$\nabla(-k \nabla T)=\frac{i_{\text {elec }}^{2}}{\sigma_{\text {elec }- \text { intercon }}}$

Air/fuel channels

$\nabla\left(-\mathrm{k} \nabla \mathrm{T}+\rho \mathrm{C}_{\mathrm{p}} \mathrm{T} \cdot \overline{\mathrm{v}}\right)=0$

Ion conservation

Anode

$-\nabla\left(\sigma_{\text {ion,anode }}^{\text {eff }} \nabla \phi_{\text {ion }}\right)=S_{\text {ion,anode }}$

Electrolyte

$-\nabla\left(\sigma_{\text {ion,elec }}^{\text {eff }} \nabla \phi_{\text {ion }}\right)=S_{\text {ion,elec }}=0$

Cathode

$-\nabla\left(\sigma_{\text {ion,cathode }}^{\text {eff }} \nabla \phi_{\text {ion }}\right)=S_{\text {ion,cathode }}$

Electron conservation

Anode

$-\nabla\left(\sigma_{\text {elec, anode }}^{\text {eff }} \nabla \phi_{\text {elec }}\right)=S_{\text {elec, anode }}$

Electrolyte

$-\nabla\left(\sigma_{\text {elec, inter }}^{\text {eff }} \nabla \phi_{\text {elec }}\right)=S_{\text {elec, inter }}=0$

Cathode

$-\nabla\left(\sigma_{\text {elec, cathode }}^{\text {eff }} \nabla \phi_{\text {elec }}\right)=S_{\text {elec, cathode }}$

The cell potential, $\phi_{\text {cell }}$, was computed from the following relationship:

$\phi_{\text {cell }}=\phi_{\text {ideal }}-\phi_{\text {ele }}-\eta_{\text {act, anode }}-\eta_{\text {act, cathode }}-\eta_{\mathrm{s}}$

where: $\phi_{\text {ele }}$ is the Ohmic overpotential of the electrolyte, $\eta_{\text {act, anode }}$ and $\eta_{\text {act,cathode }}$ represent respectively the activation overpotential of the anode and cathode, $\eta_{\mathrm{s}}$ represents the Ohmic losses in the solid conduction regions such as current collectors, while $\phi_{\text {ideal }}$ represents the Nernst potential, $\phi_{\text {Nernst }}$, described by Eq. 26:

$\phi_{\text {Nernst }}=\frac{\Delta \mathrm{G}(\mathrm{T})}{2 \mathrm{~F}}+\frac{\mathrm{RT}}{2 \mathrm{~F}} \ln \frac{\mathrm{p}_{\mathrm{H}_{2}} \cdot \mathrm{p}_{\mathrm{O}_{2}}^{1 / 2}}{\mathrm{p}_{\mathrm{H}_{2} \mathrm{O}}}$

In order to estimate the activation overpotentials for anodes and cathodes the Newton method was used to solve the Butler-Volmer equation 27:

$i=i_{0, \text { eff }}\left[\exp \left(\frac{\alpha_{\text {anode }} m \eta_{\text {act,anode }} F}{R T}\right)-\right.$

$\left.-\exp \left(\frac{\alpha_{\text {cathode }} m \eta_{\text {act,cathode }} F}{R T}\right)\right]$

In Eq. (27), $i$ is the current density, $\mathrm{i}_{0, \text { eff }}$ is the effective exchange current density, $\alpha_{\text {anode }}$ and $\alpha_{\text {cathode }}$ are anodic and cathodic transfer coefficients, respectively. The coefficients were defined as 0.5 , because of the nearly universal assumption that there was a symmetric balance between the forward and backward reactions. In addition, $F$ is the Faraday's constant, $n$ is the number of electrons that are released per reaction, $R$ is the universal gas constant, $T$ is the absolute temperature. The effective exchange current density, $\mathrm{i}_{0, \mathrm{eff}}$, at the anode and cathode side can be written as:

$\mathrm{i}_{0, \mathrm{eff}}^{\text {anode }}=\mathrm{i}_{0, \text { ref }}^{\text {anode }}\left(\frac{\chi_{\mathrm{H}_{2}}}{\chi_{\mathrm{H}_{2}, \text { ref }}}\right)^{\gamma_{\mathrm{H}_{2}}}\left(\frac{\chi_{\mathrm{H}_{2} \mathrm{O}}}{\chi_{\mathrm{H}_{2} \mathrm{O}, \text { ref }}}\right)^{\gamma_{\mathrm{H}_{2} \mathrm{O}}}$

$\mathrm{i}_{0, \text { eff }}^{\text {cathode }}=\mathrm{i}_{0, \text { ref }}^{\text {cathode }}\left(\frac{\chi_{\mathrm{O}_{2}}}{\chi_{\mathrm{O}_{2}, \text { ref }}}\right)^{\gamma_{\mathrm{O}_{2}}}$

where $i_{0, \text { ref }}$ is the exchange current density at the reference condition, $\chi_{j}$ is the mole fraction and $\gamma_{j}$ is the concentration exponent for species $j$.

The species sources or sinks appearing in Eqs. 19-24 for the anodic (Eqs. 30, 31) and cathodic (Eq. 32) molar fluxes, respectively, are the following:

$\mathrm{S}_{\mathrm{H}_{2}}=-\frac{\mathrm{i}}{2 \mathrm{~F}}$

$\mathrm{S}_{\mathrm{H}_{2} \mathrm{O}}=\frac{\mathrm{i}}{2 \mathrm{~F}}$

$S_{O_{2}}=-\frac{i}{4 F}$

The following reactions for a planar SOFC, fed with hydrogen to the anode side and oxygen to the cathode side, were considered:

$\mathrm{H}_{2}+\mathrm{O}^{2-} \Leftrightarrow \mathrm{H}_{2} \mathrm{O}+2 \mathrm{e}^{-}$

$\frac{1}{2} \mathrm{O}_{2}+2 \mathrm{e}^{-} \Leftrightarrow \mathrm{O}^{2-}$

Flow channels were designed to connect two pairs of opposite orifices at four corners of the SOFC plates. Each of the bipolar plates had an air channel system on one ribbed side and a fuel channel system on the other side as shown in Figure 3. The fuel and air inlets are located at the bottom edge of the cell on its opposite sides: fuel at the left side and air at the right side (Fig. 3). 


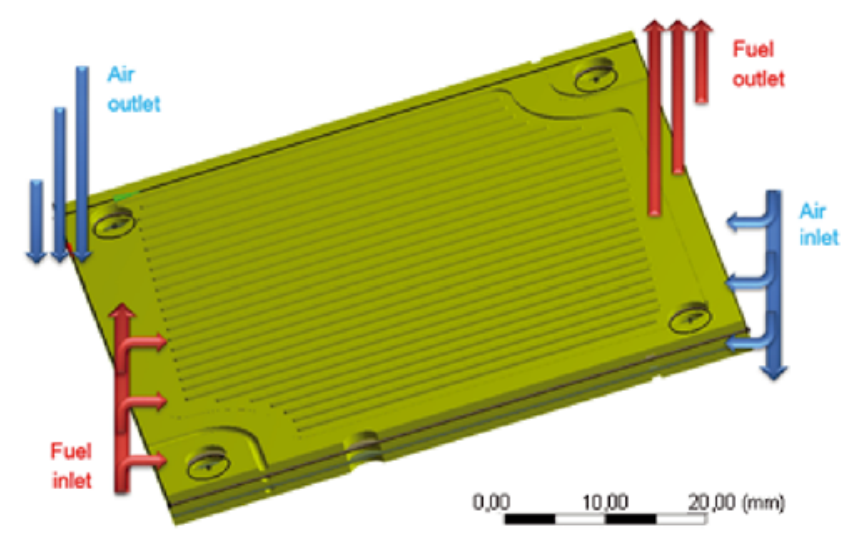

Figure 3. Flow field arrangements ${ }^{20}$

One pair of channels in adjacent plates is used for the air flow along their cathode electrodes, the opposite pair is designated for the fuel flow along the anodes of the neighbouring cells. The basic dimensions of the fuel cell are presented in Table 1 .

Table 1. Key geometry parameters ${ }^{22}$

\begin{tabular}{|l|c|c|}
\hline Parameter & Value & Dimension \\
\hline Anode thickness & 0.25 & $\mathrm{~mm}$ \\
\hline Electrolyte thickness & 0.01 & $\mathrm{~mm}$ \\
\hline Cathode thickness & 0.06 & $\mathrm{~mm}$ \\
\hline $\begin{array}{l}\text { Thickness of the } \\
\text { bipolar plate with } \\
\text { channels }\end{array}$ & 1 & $\mathrm{~mm}$ \\
\hline $\begin{array}{l}\text { Depth of the flow } \\
\text { channels }\end{array}$ & 0.35 & $\mathrm{~mm}$ \\
\hline $\begin{array}{l}\text { Diameter of the fuel } \\
\text { and air flow holes }\end{array}$ & 4.2 & $\mathrm{~mm}$ \\
\hline $\begin{array}{l}\text { Dimensions of fuel } \\
\text { cell, bipolar plates } \\
\text { and fuel/air channels }\end{array}$ & $60 \times 60$ & $\mathrm{~mm}^{2}$ \\
\hline $\begin{array}{l}\text { Active area of the fuel } \\
\text { cell }\end{array}$ & 27 & $\mathrm{~cm}^{2}$ \\
\hline $\begin{array}{l}\text { Number of ribs with } \\
\text { a different length }\end{array}$ & 26 & - \\
\hline
\end{tabular}

The operating conditions and input parameters for the developed model are listed in Tables 2-3. In order to quantify the effect of the hydrogen starvation within the planar SOFC, two cases of different mass flow rates of hydrogen were simulated numerically. In the first case (case I), which mimicked the experimental conditions $^{22}$, the hydrogen mass flow rate was equal to the value used in the measurement. In the second, fictitious case (case II), it was assumed that the mass flow rate of hydrogen should be increased and it was equal to $9.9 \cdot 10^{-8}[\mathrm{~kg} / \mathrm{s}]$.

For the momentum, energy and species differential equations the second order upwind discretization scheme was used, while for the pressure equation the second order discretization scheme was applied. Discretization of the electric potential within the first order upwind
Table 2. Major boundary conditions of the SOFC model

\begin{tabular}{|l|c|c|}
\hline Domain region & Parameter & Value \\
\hline \multirow{5}{*}{ Air inlet } & Mass flow rate: & $1.7 \cdot 10^{-6} \mathrm{~kg} / \mathrm{s}$ \\
\cline { 2 - 3 } & Temperature: & $973 \mathrm{~K}$ \\
\cline { 2 - 3 } & $\begin{array}{c}\text { Mass fraction of } \\
\text { species: }\end{array}$ & $\begin{array}{c}23.3 \% \mathrm{O}_{2}, \\
76.7 \% \mathrm{~N}_{2}\end{array}$ \\
\hline \multirow{4}{*}{ Fuel inlet } & $\begin{array}{c}\text { Mass flow rates } \\
\text { in case I: } \\
\text { in case II: }\end{array}$ & $\begin{array}{c}4.9 \cdot 10^{-8} \mathrm{~kg} / \mathrm{s} \\
9.9 \cdot 10^{-8} \mathrm{~kg} / \mathrm{s}\end{array}$ \\
\cline { 2 - 3 } & Temperature: & $973 \mathrm{~K}$ \\
\cline { 2 - 3 } & $\begin{array}{c}\text { Mass fraction of } \\
\text { species: }\end{array}$ & $\begin{array}{c}95.0 \% \mathrm{H}_{2} \\
5.0 \% \mathrm{H}_{2} \mathrm{O}\end{array}$ \\
\hline Air outlet & Pressure: & $1 \cdot 10^{5} \mathrm{~Pa}$ \\
\cline { 2 - 3 } $\begin{array}{l}\text { Outer current collector } \\
\text { (anode side) surface }\end{array}$ & $\begin{array}{c}\text { Mass fraction of } \\
\text { species: }\end{array}$ & $\begin{array}{c}17.7 \% \mathrm{~K} \\
82.3 \% \mathrm{~N}_{2},\end{array}$ \\
\hline $\begin{array}{c}\text { Voltage tap } \\
\text { Surface: } \\
\text { (cathode side) surface }\end{array}$ & $\begin{array}{c}\text { Current tap } \\
\text { surface: }\end{array}$ & $0 \mathrm{~V}$ \\
\hline Anode & $\begin{array}{c}\text { Exchange current } \\
\text { density }\end{array}$ & $7460 \mathrm{~A} \cdot \mathrm{m}^{2}$ \\
\hline Cathode & $\begin{array}{c}\text { Exchange current } \\
\text { density }\end{array}$ & $10090 \mathrm{~A} \cdot \mathrm{m}^{2}$ \\
\hline
\end{tabular}

scheme was considered, while for gradient estimations the Green Gauss node was used.

The presented model was also based on the following assumptions: steady state conditions were considered, fuel and air channels were treated as adiabatic, radiation heat exchange between MEA - Membrane Electrode Assembly and interconnectors was neglected, heat convection was neglected in the porous electrodes. The studied cases for the two chosen mass flow rates of hydrogen were numerically solved for the operating temperature of $700^{\circ} \mathrm{C}$ and for a broad range of cell voltage from 0.3 to $1.1 \mathrm{~V}$. In both cases, all residual limits were set up below $1 \cdot 10^{-6}$ and several key values were monitored. At the end of iteration they showed little value fluctuation indicating suitable level of convergence. Polarization curves at the chosen temperature were calculated by keeping the adjustable parameters constant.

\section{RESULTS AND DISCUSSION}

Analysis of the simulation results was initially focused on verification of the $\mathrm{I}-\mathrm{V}$ curve predictions with the corresponding experimental data ${ }^{22}$. Finally, distributions of species at the electrolyte layer on the anode side as well as distributions of temperature, velocity magnitude and pressure as a function of voltage were presented.

Comparison of the CFD results with experimental result $^{22}$ revealed a few different points. Firstly, for the current density values higher than $8[\mathrm{~A}]$ achieved within the SOFC from simulation for the case I, deviations from the experimental results were noticed (Fig. 4).

The CFD curves marked by black squares for original mass flow rate of hydrogen within the SOFC correspond

Table 3. Properties of the fuel cell component

\begin{tabular}{|c|c|c|c|c|}
\hline Parameter & Anode & Electrolyte & Cathode & Current collectors \\
\hline Material & $\mathrm{Ni}-\mathrm{YSZ}$ & YSZ & LSM & - \\
\hline Density $\mathrm{kg} / \mathrm{m}^{3}$ & 7740 & 6000 & 5300 & 7450 \\
\hline Specified heat capacity $\mathrm{J} / \mathrm{kgK}$ & 595 & 400 & 607 & 600 \\
\hline Thermal conductivity $\mathrm{W} / \mathrm{mK}$ & 6.23 & 2.7 & 10 & 27 \\
\hline Resistivity Ohm 'm & - & 0.1 & - & - \\
\hline Electronic conductivity $1 / \mathrm{Ohm} \cdot \mathrm{m}$ & 30300 & - & 12800 & 769000 \\
\hline Anode-current collectors contact resistance $\mathrm{Ohm} \cdot \mathrm{m}^{2}$ & $1 \cdot 10^{-7}$ & - & $1 \cdot 10^{-8}$ & - \\
\hline Porosity & 0.3 & - & 0.3 & - \\
\hline
\end{tabular}


quite well with the experimental ones ${ }^{22}$ for the operating voltage of 1.1, 0.9 and 0.7 [V], while at lower voltage values of 0.5 and 0.3 [V] significant gradients in the current were obtained. Therefore, additional simulation of case II was run at the mass flow rate of hydrogen increased twice (in comparison to the original value of mass flow rate taken from the experimental investigation) to avoid fuel starvation. It was found that for the operating voltage of 0.7 [V] the electric current slightly increased and its value (white triangles in Fig. 4) was closer to the

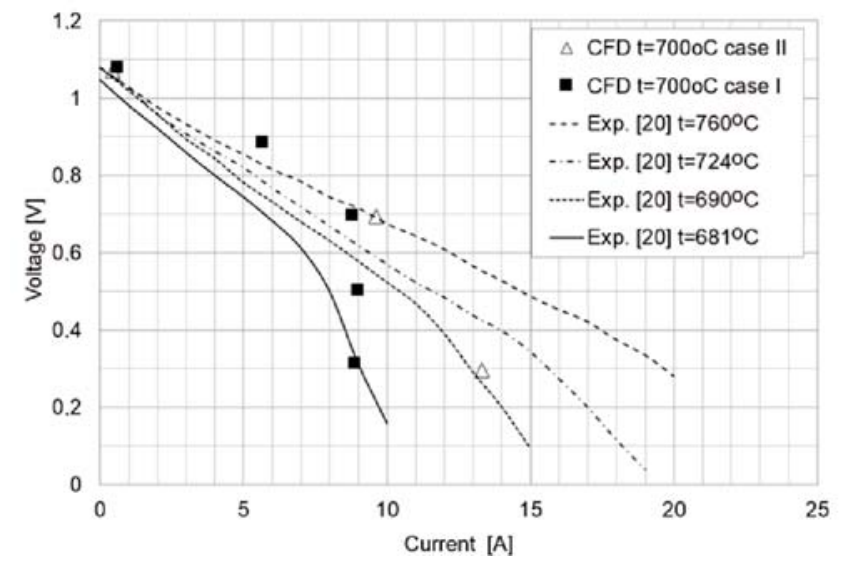

Figure 4. Polarization curves at various operating temperatures for a single planar SOFC
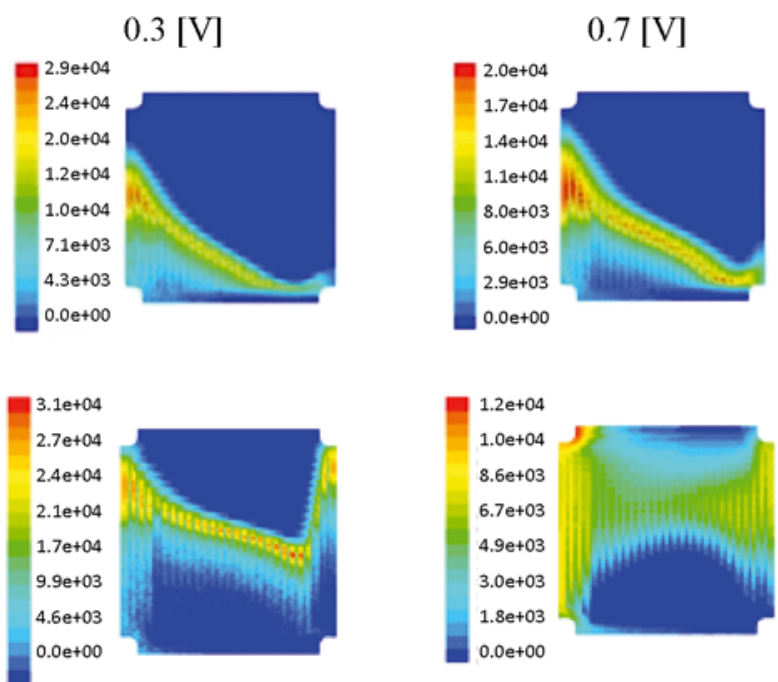

\section{$0.7[\mathrm{~V}]$}

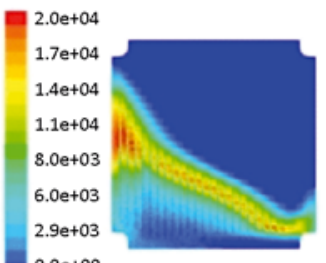

$0.0 \mathrm{e}+00$

$0.0 \mathrm{e}+00$ experimental one. The most important finding was that for the operating voltage of 0.3 [V] a significant improvement of the electrical current was noticed for case II. Its values correspond quite well with the measurements ${ }^{22}$ at the operating cell temperature of $690^{\circ} \mathrm{C}$.

Figure 5 shows the current density distributions of the modelled SOFC structure for cases I and II and at the operating cell voltage of $0.3,0.7$ and 1.1 [V].

The current density ranged from 1700 to 29000 [A/ $\mathrm{m}^{2}$ ], which is common value for the electric current for realistic SOFC under operational conditions ${ }^{25}$. The current density was non-uniform over the cell length and areas of the highest current density were identified in particular at the cell voltage of 0.3 and 0.7 [V]. An attempt to explain such SOFC behaviour was undertaken. For this purpose the hydrogen and oxygen mass fraction distributions are shown in Figures 6-7, respectively. Fuel inlet was located at the left bottom corner, while the air inlet was located at the upper left corner. The fuel and air flow directions were across the cell, perpendicular to each other.

The mass fractions of hydrogen for both considered cases I and II changed unevenly between the fuel inlet and outlet. The mass fractions of hydrogen (Fig. 6) as well as of oxygen (Fig. 7) decreased along their main flow directions. It seems from the simulations the areas

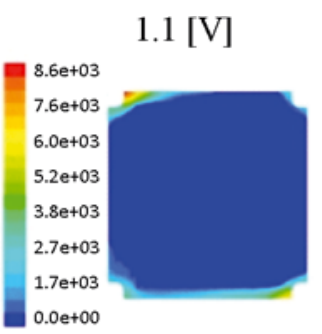

(a)

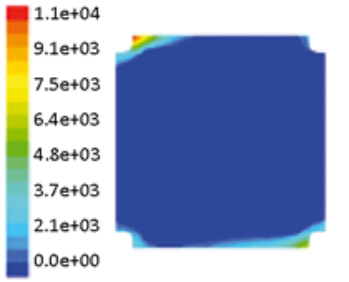

Figure 5. Current density distributions in electrolyte at the cathode side $\left[\mathrm{A} / \mathrm{m}^{2}\right]$ : (a) case $\mathrm{I}$ - original, (b) case II - artificial

0.3 [V]
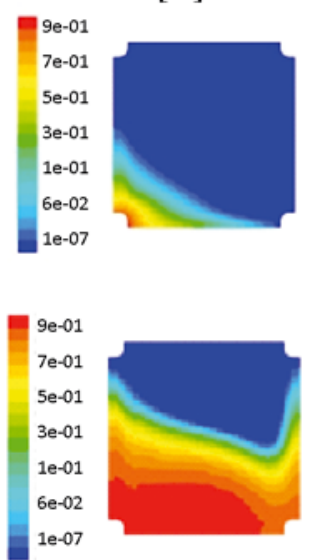

0.7 [V]

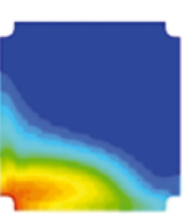

$9 e-01$
$7 e-01$
$5 e-01$
$3 e-01$
$1 e-01$
$6 e-02$
$1 e-07$

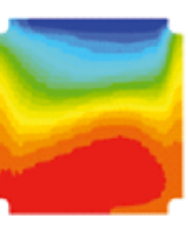

1.1 [V]
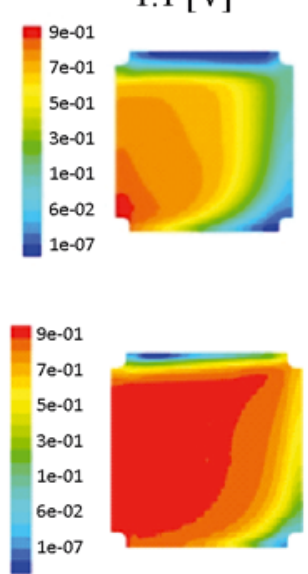

(a) (b)

II - artificial

(b)

Figure 6. Mass fraction of hydrogen distributions at the electrolyte on the anode side [kg/kg]: (a) case I, (b) case II 
$0.3[\mathrm{~V}]$
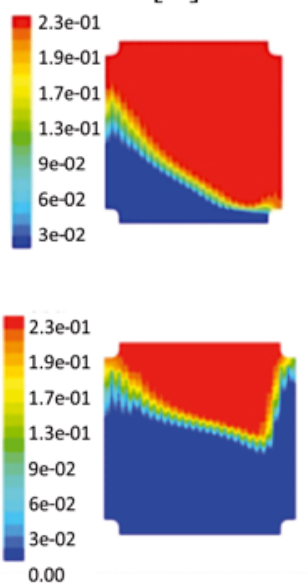

$0.7[\mathrm{~V}]$

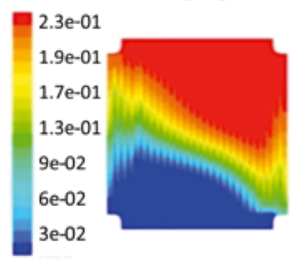

$2.0 \mathrm{e}-01$
$1.8 \mathrm{e}-01$
$1.6 \mathrm{e}-01$
$1.3 \mathrm{e}-01$
$9 \mathrm{e}-02$
$6 \mathrm{e}-02$
$3 \mathrm{e}-02$
0.00

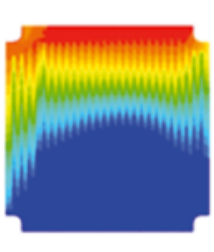

$1.1[\mathrm{~V}]$

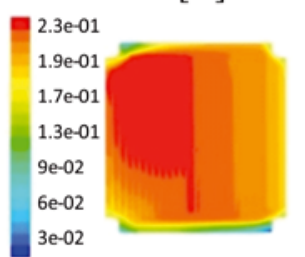

(a)

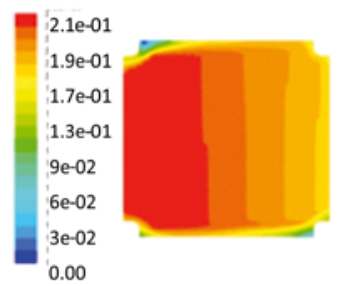

(b)

Figure 7. Mass fraction of oxygen distributions in the electrolyte at the cathode side [kg/kg]: (a) case I, (b) case II

where hydrogen was available were electrochemically highly active and the cell was locally able to produce current at the applied voltage, while in the areas where local fuel starvation could be noticed, the cell could not produce enough electrical current. It has to be underlined that areas where the hydrogen and oxygen concentrations strongly decreased (Figs. 6 and 7) overlap with regions of the highest current density (Fig. 5). In those regions the highest electrochemical reaction rates were noticed and therefore high mass fractions of water steam for case I can be noticed from those regions up to the fuel outlet (Fig. 8).

For the case II, when the inlet hydrogen mass flow rate was doubled, areas of high water steam concentration were shifted into the central part of the fuel cell, which suggests that hydrogen starvation was limited and more uniform species distributions across the cell were obtained (Figs. 6-8 b).

One of the key parameters affecting the performance characteristics of the planar SOFC is the operating pressure, which affects transport properties and electrochemical behaviour. In the planar SOFC design proposed by Bossel $^{22}$ the pressure drop in the fuel channel ranged from 18.9 to 12.9 [Pa] for case I and from 31.8 to 29.9 [Pa] for case II, respectively for voltage values from 0.3 to 1.1 [V]. In both considered cases, I and II, the pressure distributions presented in Figure 9 were quite uniform across the cell.

The SOFC should preferably operate around its maximum power density at high electric efficiency and without local fuel starvation. To achieve these conditions the fuel velocity needs to be properly controlled. Figure 10 shows the gas velocity distributions in the fuel channel at the 3 operating voltages. The hydrogen fuel enters the anode channel in the lower left corner at the velocity of $1.5-1.7[\mathrm{~m} / \mathrm{s}]$ for case I and $2.9-4.2[\mathrm{~m} / \mathrm{s}]$ for case II. Then the hydrogen flows along 27 sub-channels with a different length and leaves the anode channel through the fuel outlet located at the upper right corner. In both cases, the highest gas velocities were noticed at the inlet, then it dropped slightly and increased again in the outlet region of the planar fuel cell. As it can be seen from Figure $10 \mathrm{~b}$, the gas velocity of the planar fuel cell for case II with the mean value of $0.7[\mathrm{~m} / \mathrm{s}]$ ensures that the current density safety varies from 1700 to $29000\left[\mathrm{~A} / \mathrm{m}^{2}\right]$ without fuel starvation, whereas high fuel utilization, electric efficiency and maximum power density can be achieved.

Additionally, temperature distributions in the fuel channel for both considered cases are presented in Figure 11. The temperature distributions were strongly non-uniform. The maximum fuel temperature was identified

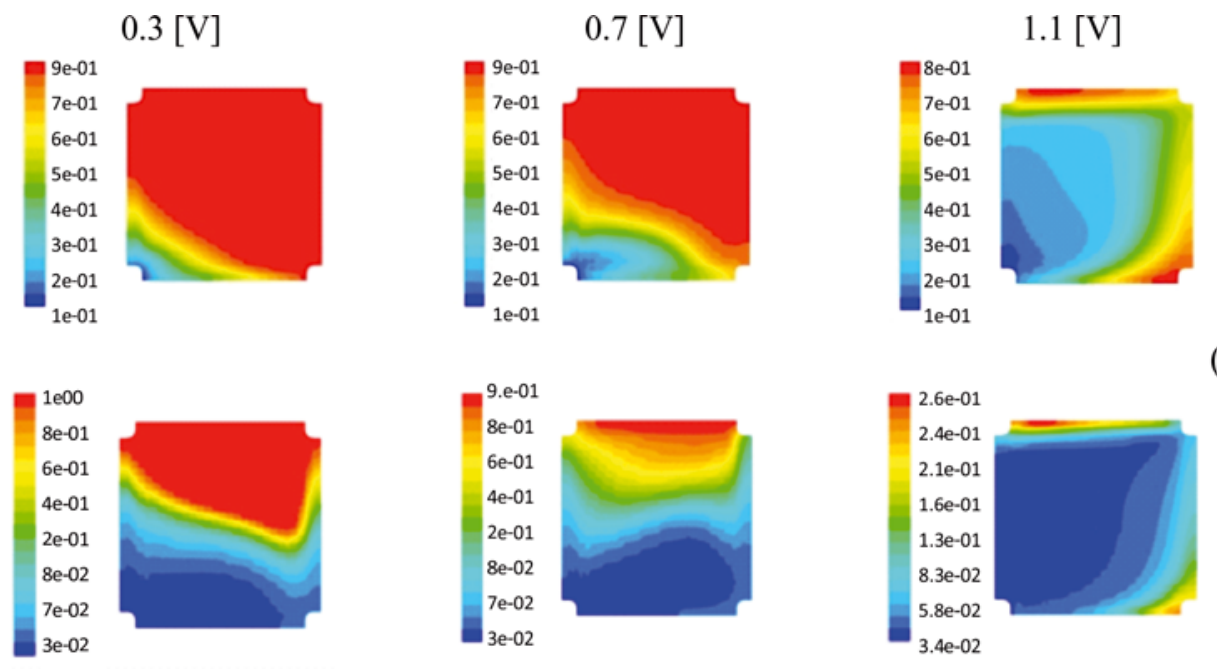

(a)

(b)

Figure 8. Water mass fraction distributions in the electrolyte at the anode side [kg/kg]: (a)case I, (b) case II 

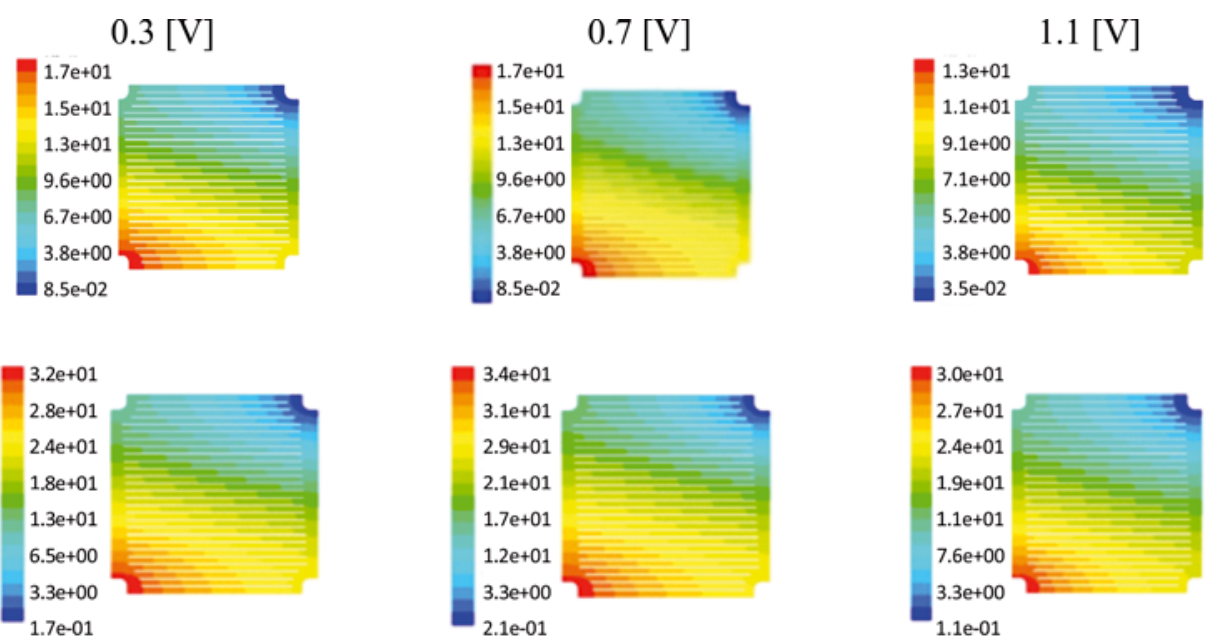

(a)

(b)

Figure 9. Distributions in the fuel channel of pressure [Pa]: (a) case I, (b) case II

\section{$0.3[\mathrm{~V}]$}
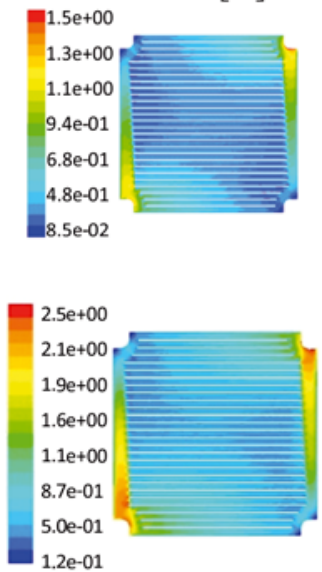

$0.7[\mathrm{~V}]$

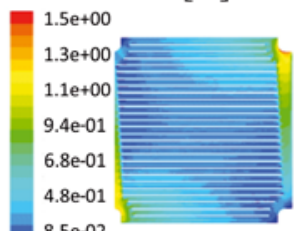

$8.5 \mathrm{e}-02$

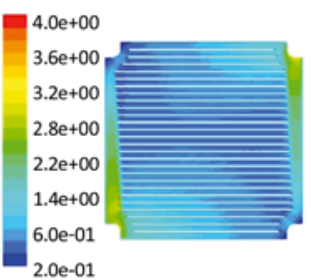

$1.1[\mathrm{~V}]$

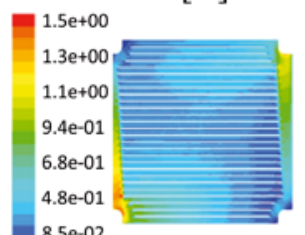

(a)

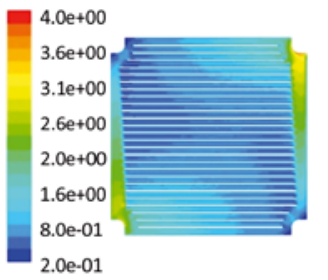

(b)

Figure 10. Distributions in the fuel channel of velocity [m/s]: (a) case I, (b) case II

in the area of the air outlet at the lower right corner and also in the area, where formation of the products increased. In addition, these areas overlapped with the areas of the highest values of the current density shown in Figure 5. The average temperature difference between the fuel inlet and outlet was equal to $150^{\circ} \mathrm{C}$ for case I, while $270^{\circ} \mathrm{C}$ for case II. Such high temperature difference may cause thermal stresses and lead to fuel cell failure.
Therefore, thermal stresses analysis in a planar SOFC needs to be investigated in further steps.

\section{CONCLUSIONS}

Insight into the cause and potential solutions of the fuel starvation problem was gained by numerical simulations. The analysis of cell performance during hydrogen starvation in the single planar SOFC with complex flow channels design was carried out using the CFD tool.
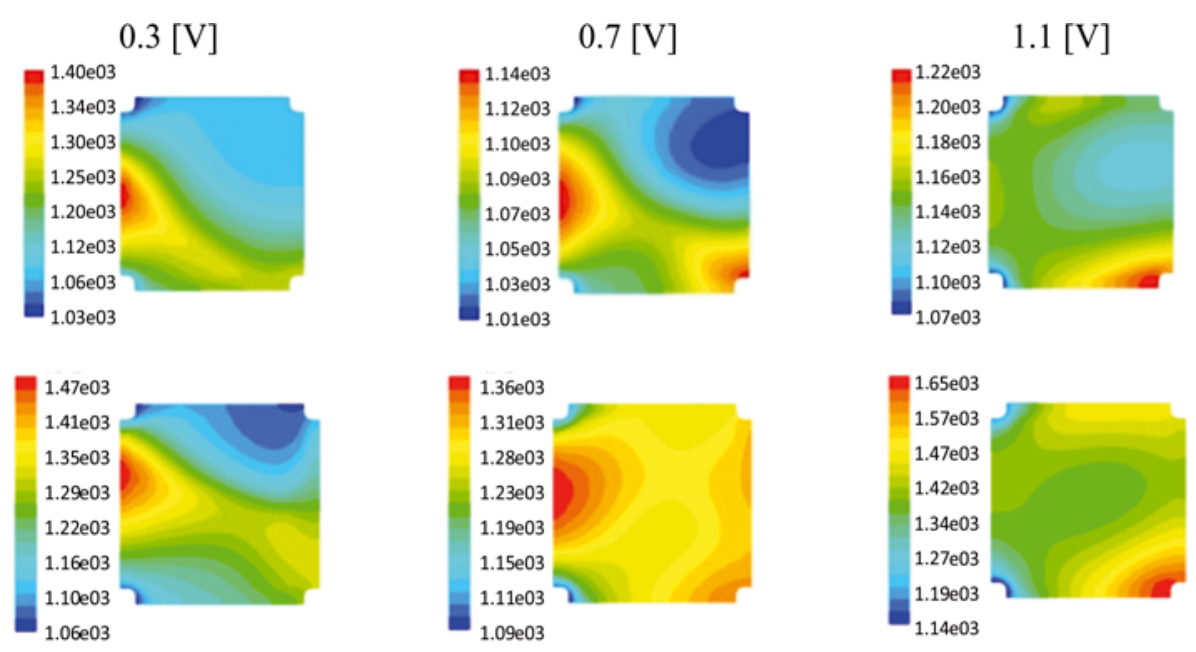

(a)

(b)

Figure 11. Distributions in the fuel channel of temperature $[\mathrm{K}]$ : (a) case I, (b) case II 
It was shown that the change of the fuel mass flow rate plays a significant role in the SOFC performance. An appropriate selection of the fuel flow rate can improve the current-voltage characteristics and power curve. Due to the selection of the fuel flow rate, the fuel distribution in the anode becomes more uniform and therefore the local fuel starvation effect was avoided. As a result the effective active surface of the electrolyte increases as well. A higher level of the fuel distribution uniformity influences into the more uniform current density distribution in the SOFC. In addition, the appropriate selection of the fuel flow rate reduces the risk of local fuel cell degradation due to non-uniformity distribution of temperature.

A typical and the most optimal in terms of the SOFC efficiency value of the operational voltage was equal to $0.7 \mathrm{~V}$. The voltage change to two extreme values of 0.3 and $1.1 \mathrm{~V}$ resulted in both cases to temperature increased. Both cases can be called as critical and the operational conditions should be avoided due to the risk of fuel cell damage. In addition, at a low voltage value of 0.3 $\mathrm{V}$, there was a high risk of the fuel starvation, while at high voltage value of $1.1 \mathrm{~V}$, there was a risk of a low level of the fuel usage for power production.

In the future, an influence of the fuel flow rate changes into thermal stress distribution in the SOFC will be investigated in order to perform the stress analysis and to identify the most loaded components and regions in the SOFC.

\section{NOMENCLATURE}

$\mathrm{C}_{\mathrm{p}} \quad$ - average specific heat, $\left[\mathrm{Jkg}^{-1} \mathrm{~K}^{-1}\right]$

$\mathrm{D}_{\mathrm{i}, \mathrm{k}} \quad-$ mass diffusivity coefficient, $\left[\mathrm{m}^{2} \mathrm{~s}^{-1}\right]$

$D_{i, k}^{e f f} \quad-$ effective diffusivity between species $i$ and $k$, $\left[\mathrm{m}^{2} \mathrm{~s}^{-1}\right]$

$F \quad-$ Faraday's constant, $\left.\mathrm{Cmol}^{-1}\right]$

$\mathrm{G} \quad-$ Gibbs free energy, $\left[\mathrm{Jmol}^{-1}\right]$

i - current density, $\left[\mathrm{Am}^{-2}\right]$

$i \quad-$ species $\mathrm{H}_{2}, \mathrm{H}_{2} \mathrm{O}, \mathrm{O}_{2}$

I - current, [A]

$\mathrm{i}_{0, \text { eff }} \quad-$ effective exchange current density, $\left[\mathrm{Cm}^{-2} \mathrm{~s}^{-1}\right]$

$\mathrm{i}_{0, \text { ref }} \quad-$ exchange current density at the reference condition, $\left[\mathrm{Cm}^{-2} \mathrm{~s}^{-1}\right]$

$\mathrm{k}-$ - thermal conductivity, $\left[\mathrm{Wm}^{-1} \mathrm{~K}^{-1}\right]$

$M_{\mathrm{i}} \quad-$ molar mass of species $i,\left[\mathrm{kgmol}^{-1}\right]$

$n-$ number of electrons that are released per reaction, [-]

$\mathrm{p} \quad-$ pressure, $[\mathrm{Pa}]$

$Q_{\mathrm{i}} \quad-$ heat flux of species $i,\left[\mathrm{Wm}^{-2}\right]$

$R \quad$ - universal gas constant, $\left[\mathrm{Jkmol}^{-1} \mathrm{~K}^{-1}\right]$

$\mathrm{R}_{\mathrm{i}} \quad$ - source term, mol m $\left.\mathrm{m}^{-3} \mathrm{~s}^{-1}\right]$

$\mathrm{S}_{\mathrm{i}} \quad-$ molar flux of species $i$, $\left[\mathrm{mol} \mathrm{m} \mathrm{m}^{-2} \mathrm{~s}^{-1}\right.$ ]

$\mathrm{T}$ - temperature, $[\mathrm{K}]$

$\mathrm{V} \quad-$ voltage, [V]

$\bar{v}_{i} \quad-$ velocity vector, $\left[\mathrm{ms}^{-1}\right]$

$x_{\mathrm{i}} \quad-$ mass fraction of species $i,\left[\mathrm{kgkg}^{-1}\right]$

\section{Greek symbols}

$\alpha_{\text {anodea }}-$ anodic transfer coefficient, [-]

$\alpha_{\text {cathode }}-$ cathodic transfer coefficient, [-]

$\chi_{\mathrm{i}}-$ mole fraction, $\left[\mathrm{mol} \mathrm{mol}{ }^{-1}\right.$ ]

$\varepsilon \quad$ - electrode porosity, [-]

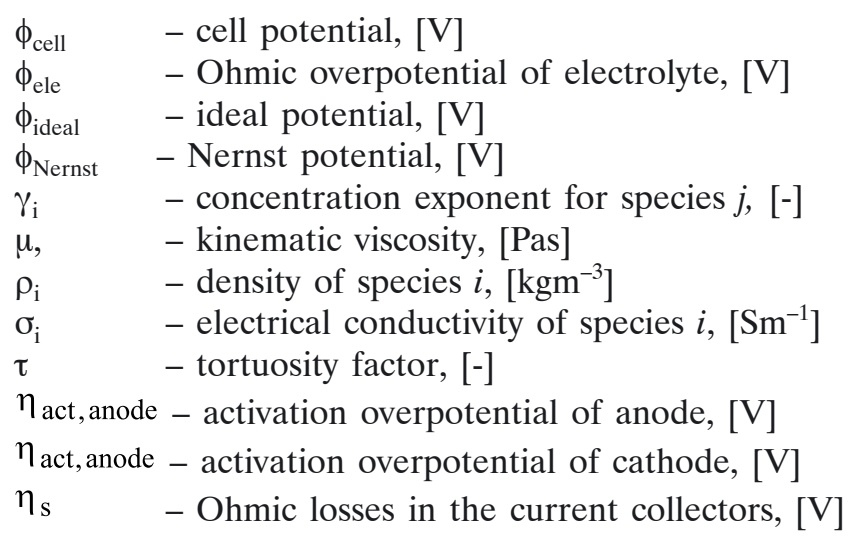

\section{ACKNOWLEDGEMENTS}

The research programme leading to these results received funding from the European Union's Seventh Framework Programme (FP7/2007-2013) for the Fuel Cells and Hydrogen Joint Undertaking (FCH JU) under grant agreement $n^{\circ}$ [325323]. Information contained in the paper reflects only view of the authors. The FCH JU and the Union are not liable for any use that may be made of the information contained therein. Acknowledgments are due to the partners of SAFARI project.

The work was also financed from the Polish research funds awarded for the project No. 3043/7.PR/2014/2 of international cooperation within SAFARI in years 2014-2016.

\section{LITERATURE CITED}

1. Theo, W.L., Lim, J.S., Ho, W.S., Hashim, H. \& Lee, Ch.T. (2017). Review of distributed generation (DG) system planning and optimisation techniques: comparison of numerical and mathematical modelling methods. Renewable \& Sustainable Energy Rev. 67, 513-573. DOI: 10.1016/j.rser.2016.

2. Albrecht, K.J. \& Braun, R.J. (2016). The effect of coupled mass transport and internal reforming on modeling of solid Oxide fuel cells part I: channel-level model development and steady-state comparison. J. Power Sources, 304, 384-401. DOI: 10.1016/j.jpowsour.2015.11.043.

3. Amiri, A., Vijay, Tade, P.M.O., Ahmed, K., Ingram, G.D., Pareek, V. \& Utikar, R. (2016). Planar SOFC system modelling and simulation including a 3D stack module, International J. Hydro. Energy 41, 2919-2930. DOI: 10.1016/j. ijhydene.2015.12.076.

4. Akhtar, N., Decent, S.P. \& Kendall, K. (2010). Numerical modelling of methane powered micro-tubular, single-chamber solid oxide fuel cell. J. Power Sources, 195, 7796-7807. DOI: 10.1016/j.jpowsour.2010.01.084.

5. Yurkiv, V. (2014). Reformate-operated SOFC anode performance and degradation considering solid carbon formation: A modeling and simulation study. Electrochimica Acta 143, 114-128. DOI: 10.1016/j.electacta.2014.07.136.

6. Gaynor, R., Mueller, F., Jabbari, F. \& Brouwer, J. (2008). On control concepts to prevent fuel starvation in solid oxide fuel cells, J. Power Sources 180, 330-342. DOI: 10.1016/j. jpowsour.2008.01.078.

7. Stiller, C., Thorud, B., Seljebo, S., Mathisen, O., Karoliussen, H. \& Bolland, O. (2005). Finite volume modeling and hybrid cycle performance of planar and tubular solid oxide fuel cells, J. Power Sources 141(2), 227-240. DOI: 10.1016/j. jpowsour.2004.09.019.

8. Kandepu, R., Imsland, L., Foss, B. A., Stiller, C., Thorud, B. \& Bolland, O. (2007). Energy 32(4), 406-417. DOI: 10.1016/j. energy.2006.07.034. 
9. Lee, T.H., Park, K.Y., Kim, J.T., Seo, Y., Kim, K.B., Song, K.B., Park, B. \& Park, J.Y. (2015). Degradation analysis of anode-supported intermediate temperature - solid oxide fuel cells under various failure modes, J. Power Sources 276, 120-132. DOI: 10.1016/j.jpowsour.2014.11.077.

10. Chen, G., Guan, G., Abliz, S., Kasai, Y. \& Abudula, A. (2011). Rapid degradation mechanism of Ni-CHO anode in low concentrations of $\mathrm{H} 2$ at a high current density. Intern. J. Hydrogen Energy 36, 8461-8467. DOI: 10.1016/j/ijhydene.2011.04.046.

11. Brus, G., Miyoshi, K., Iwai, H., Saito, M. \& Yoshida, H. (2015). Change of an anode's microstructure morphology during the fuel starvation of an anode-supported solid oxide fuel cell. Intern. J. Hydrogen Energy 40, 6927-6934. DOI: 10.1016/j/ ijhydene.2015.03.143.

12. Sarantaridis, D., Rudkin, R.A. \& Atkinson, A. (2008). Oxidation failure modes of anode-supported solid oxide fuel cells. J. Power Sources 180, 704-710.

13. Hatae, T., Matsuzaki, Y., Yamashita, S. \& Yamazaki, Y. (2009). Current density dependence of changes in the microstructure of SOFC anodes during electrochemical oxidation.Solid State Ionics 180, 23-25, 1305-1310. DOI: 10.1016/j. ssi.2009.08.003.

14. Fang, Q., Blum, L., Peters, R., Peksen, M., Batfalsky, P. \& Stolten, D. (2015). SOFC stack performance under high fuel utilization. Intern. J. Hydrogen Energy 40, 1128-1136. DOI: 10.1016/j.ijhydene.2014.11.094.

15. Fang, Q., Blum, L., Batfalsky, P., Menzler, N.H., Packbier, U. \& Stolten, D. (2013). Durability test and degradation behaviour of a $2.5 \mathrm{~kW}$ SOFC stack with internal reforming of LNG. Intern. J. Hydrogen Energy 38, 36, 16344-16353. DOI: 10.1016/j.ijhydene.2013.09.140.

16. Majewski, A.J. \& Dhir, A. (2015). Direct utilization of methane in microtubular SOFC, ECS Transactions, 68, 1, 2189-2198, 10.1149/06801.2189ecst. Solid Oxide Fuel Cells 14, SOFC-XIV.

17. Torrell, M., Morata, A., Kayser, P., Kendall, M., Kendall, K., Tarancon, A. (2015). Performance and long term degradation of $7 \mathrm{~W}$ micro-tubular solid oxide fuel cell for portable applications. J. Power Sources 285, 439-448. DOI: 10.1016/j. jpowsour.2015.03.030.

18. Lawlor, V. (2013). Review of the micro-tubular solid oxide fuel cell (part II: cell design issues and research activities). J. Power Sources 240, 421-441. DOI: 10.1016/j.jpowsour.2013.03.191.

19. Koshiyama, T., Nakajima, H., Karimata, T., Kitahara, T., Ito, K., Masuda, S., Ogura, Y. \& Shimano, J. (2015). Direct current distribution measurement of an electrolytesupported planar Solid Oxide Fuel Cell under the rib and channel by segmented electrodes. ECS Trans. 68(1), 2217-2226.10.1149/06801.2217ecst. Solid Oxide Fuel Cells 14, SOFC-XIV.

20. Sezer, H., Celik, I.B. \& Yang, T. (2015). Electrochemical behaviour of phosphine induced anode performance degradation in a planar SOFC: a numerical study. ECS Trans.68(1), 2515-2525. 10.1149/06801.2515ecst. Solid Oxide Fuel Cells 14, SOFC-XIV.

21. Zhang, Z., Chen, J., Yue, D., Yang, G., Ye, S., He, C., Wang, W., Yuan, J. \& Huang, N. (2014). Three-dimensional CFD modeling of transport phenomena in a cross-flow anodesupported planar SOFC. Energies 7, 80-98. DOI: 10.3390/ en7010080.

22. Bossel, U. (2015). Small scale power generation for road trucks with planar SOFC system. ECS Transactions 68(1), 193-199. 10.1149/06801.193ecst. Solid Oxide Fuel Cells 14, SOFC-XIV.

23. Pianko-Oprych, P., Kasilova, E. \& Jaworski, Z. (2014). Quantification of the radiative and convective heat transfer processes and their effect on mSOFC by CFD modelling. PJChT, 16(2), 51-55. DOI: 10.2478/pjct-2014-0029.
24. Pianko-Oprych, P., Zinko, T. \& Jaworski, Z. (2016). Simulation of the steady-state behaviour of a new design of a single planar Solid Oxide Fuel Cell. Pol. J. Chem. Technol. 18(1), 64-71. DOI: 10.1515/pjct-2016-0011.

25. Kakac, S., Pramuanjaroenkij, A. \& Zhou, X.Y. (2007). A review of numerical modeling of solid oxide fuel cells, Intern. J. Hydrogen Energy 32, 761-786. DOI: 10.1016/j. ijhydene.2006.11.028. 